\title{
Development of Myrmeleon brasiliensis (Navás) (Neuroptera, Myrmeleontidae), in laboratory, with different natural diets
}

\author{
Giani L. B. Missinian 1; Manoel A. Uchôa-Fernandes ${ }^{2}$ \& Erich Fischer ${ }^{3}$
}

\author{
${ }^{1}$ Curso de Ciências Biológicas, Centro Universitário da Grande Dourados. Rua Balbina de Matos 2121, 79824-900 \\ Dourados, Mato Grosso do Sul, Brasil. \\ 2 Faculdade de Ciências Biológicas e Ambientais, Universidade Federal da Grande Dourados. Caixa Postal 241, 79804-970 \\ Dourados, Mato Grosso do Sul, Brasil. E-mail: uchoa.fernandes@ufgd.edu.br \\ ${ }^{3}$ Departamento de Biologia, Universidade Federal de Mato Grosso do Sul. 79070-900 Campo Grande, Mato Grosso do Sul, \\ Brasil.
}

\begin{abstract}
Antlions larvae are sit-and-wait predators that capture arthropod prey in conical sand pits. The aim of this paper were to determine the effect of different natural diets [leaf-cutting ants (Atta spp.), fruit fly larvae (Anastrepha spp. and Ceratitis capitata) and mixed diet (Atta spp. plus fruit fly larvae)] on the development of larvae and pupae of M. brasiliensis (Navás, 1914) and to estimate the number and size of prey caught in each instar and on each kind of diet. The average duration (days) of the second and third instars of M. brasiliensis was longer when larvae of antlion were fed with leaf-cutting ants. The diets did not affect the duration of the pupal stage nor the pupae size. The different diets did not affect the mean width of head capsule $(\mathrm{mm})$, the mean weight $(\mathrm{mg})$ or the mean body size $(\mathrm{mm})$ in the different instars of M. brasiliensis. In the second and third instars, the larvae of $M$. brasiliensis fed with leaf-cutting ants consumed more prey than larvae kept on other diets. Adults whose larvae were fed fruit fly larvae were larger than adults on other diets. Although Myrmeleontidae are few studied in Brazil, these results contribute to knowledge of M. brasiliensis biology, but also suggest the need of studies about the development of larvae and pupae in natural environments.
\end{abstract}

KEY WORDS. Antlion; life history; predation.

RESUMO. Desenvolvimento de Myrmeleon brasiliensis (Navás) (Neuroptera, Myrmeleontidae), em laboratório, com diferentes dietas naturais. Larvas de formiga-leão são conhecidas por suas armadilhas ("funis") que constroem em solo arenoso, sob as quais esperam por suas presas. Este trabalho teve como objetivos verificar o efeito de diferentes dietas naturais [formigas-cortadeiras (Atta spp.), larvas de moscas-das-frutas (Anastrepha spp. e Ceratitis capitata) e dieta mista (Atta spp. e larvas de moscas-das-frutas)] sobre o desenvolvimento larval e pupal de M. brasiliensis (Navás, 1914) e estimar o número e tamanho de presas capturadas, por instar larval, em cada dieta. No segundo e terceiro instares, as larvas de $M$. brasiliensis alimentadas com formigas-cortadeiras consumiram um número maior de presas e a duração média, em dias, foi maior nesta dieta. As dietas não influenciaram a duração do período pupal, nem o tamanho das pupas, e também não afetaram a largura da cápsula cefálica $(\mathrm{mm})$, o peso $(\mathrm{mg})$ nem o tamanho corporal $(\mathrm{mm})$ nos diferentes instares do período larval de $M$. brasiliensis. Porém, as diferentes dietas afetaram o tamanho dos adultos. Tendo em vista que os mirmeleontídeos são pouco estudados no Brasil, estes resultados contribuem para o conhecimento da biologia de M. brasiliensis, mas também sugerem a necessidade de estudos sobre o desenvolvimento larval e pupal em ambientes naturais.

PALAVRAS-CHAVE. Ciclo de vida; formiga-leão; predação.

Antlions (Neuroptera, Myrmeleontidae) are predators commonly found in tropical areas (FISHER 1989), with about 1,500 described species (Stange 2004). Antlion larvae are sitand-wait predators that capture arthropod prey in conical sand pits (ARnett \& Gotelli 2001). The construction of funnel-shaped pits occurs within the tribe Myrmeleontini (New 1991), and is characteristic of the genus Myrmeleon (LucAS \& StANGE 1981). Larvae pass through three instars, live up to two years, construct silk cocoons, and emerge as adults after approximately one month (Arnett \& Gotell 1999b, 2001). As the common name suggests, ants constitute most of the larval diet of the antlion, not by preference, but because they are usually the 
most abundant arthropods in areas where antlions are found (Topoff 1977). Other kinds of prey consumed by antlion larvae include beetles, spiders, ticks, lepidopteran larvae and other antlion larvae (GotelLI 1993).

Adult antlions resemble damselflies. They are night predators, feeblefliers, and are frequently attracted by light (NEW 1991, Gotelu 1993). After emergence, adult females oviposit eggs in the sand. Adults live about one month (Arnett \& Gotell 2001). Observation of gut contents has shown that members of many families of Neuroptera may be, at least casually, omnivorous or phytophagous. Some Nemopteridae, Myrmeleontidae, Sisyridae and Osmylidaeclearly takenon-animal food at times (New 1991).

Most of the studies on antlions refer to the use of their traps, their behavior in the capture of prey and intra and interspecific competition (e.g. WILSON 1974, HeINRICH \& HEINRICH 1984, Matsura 1987, Lucas 1989, Gotell 1997), whilefew studies have focused on larval or pupal development and the conditions under which the adults emerge. In order to contribute to the knowledge of antlions biology, the aim of this paper were to determine the effect of different natural diets on the larval and pupal development of Myrmeleon brasiliensis (Navás, 1914) and to estimate the number and size of prey caught in each instar for different diets.

\section{MATERIAL AND METHODS}

\section{Area of study}

The experiments were donein the Laboratório de Controle Biológico de Insetos, Universidade Federal de Mato Grosso do Sul at Campo Grande, Mato Grosso do Sul, Brazil, from February, 2001 to January, 2002. First, second and third instars of M. brasiliensis were collected over a period of six months, in the Forest Reserve of the Fundação Centro de Educação Rural de Aquidauana (CERA), Aquidauana, Mato Grosso do Sul, Brazil

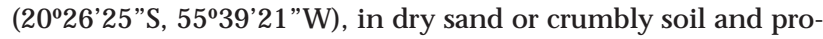
tected places such as under vegetation, under rocks, under fallen trunks, and, rarely, in unprotected places.

\section{Collection of larvae}

The larvae were collected with a spoon and transported in groups in plastic trays along with the soil from the collection places. In the laboratory, the larvae were placed individually in transparent plastic containers, approximately $13.5 \mathrm{~cm}$ in height and $10.2 \mathrm{~cm}$ in diameter, containing $6 \mathrm{~cm}$ of sterilized sand or crumbly soil from the collection place, with grains 0.08 to $0.60 \mathrm{~mm}$ in diameter. Each container was covered with fine cloth (tule) fixed by an elastic band to prevent the adults from escaping after emergence. The larvae, pupae and adults were kept under average temperature of $26.0 \pm 3.50 \circ \mathrm{C}$ (mean \pm standard deviation), average relative humidity of $65.2 \pm 5.60 \%$ (mean \pm standard deviation) and 12 hours daylength.

A total of 161 larvae of $M$. brasiliensis were raised in the laboratory. Of these, 96 were given a diet of leaf-cutting ants (Formicidae): Atta sexdens rubropilosa (Forel, 1908) and Atta laevigata (S. Smith, 1858); 36 were fed Iarvae of fruit flies (Tephritidae): Anastrepha fraterculus (Wied., 1830), A. obliqua (Macquart, 1835) and Ceratitis capitata (Wied., 1824) and 29 were given a mixed diet of leaf-cutting ants and fruit fly larvae. The larvae of $M$. brasiliensis were fed daily, generally in the morning, with one or two prey selected at random, the second prey offered immediately after the first prey was consumed.

The leaf-cutting ants were collected daily, on the campus of the Universidade Federal de Mato Grosso do Sul, at Campo Grande-MS. The fruit fly larvae were obtained from the fruits: starfruit (Averrhoa carambola L., 1758, Oxalidaceae), guava (Psidium guajava L., 1758, Myrtaceae) and mango (Mangifera indica L., 1758, Anacardiaceae), collected on the campus of the Universidade Federal de Mato Grosso do Sul, at Campo Grande and at Dourados. The fruit was placed on wooden bases, covered by a net, and put inside plastic trays. The trays contained a little water, into which the last instar larvae fell when they abandoned the fruit to pupate, according to the methodology described by UCHÔA-FERnANDES \& ZUCCHI (1999). These larvae were collected to feed the larvae of $M$. brasiliensis.

In order to estimate the size of the consumed and nonconsumed prey, the first prey was picked up randomly and offered to each individual of $M$. brasiliensis. The prey was put directly inside the "funnel". If the prey was not captured in approximately forty minutes, it was removed and considered as non-consumed. The size of the leaf-cutting ants and fruit fly larvae was obtained by measuring the body length (head apex to abdomen tip), using a calliper of $0.1 \mathrm{~mm}$ accuracy. The number of prey consumed was obtained by adding the captured and consumed prey in each instar, but only for those larvae that began the instar in the laboratory. Therefore, for the larvae of the first instar of $\mathrm{M}$. brasiliensis, the number of consumed prey was not obtained because the individuals were collected in the field al ready in that instar.

In order to estimate the size of the larvae of M. brasiliensis, the width of the head capsule was measured close to the mandibles, where the width is maximum, and the body length (mandibles to abdomen), using the calliper. The larvae were also weighed on a scale with a precision of $0.0001 \mathrm{~g}$. Measurements were taken at the beginning of each instar, i.e., after molting and before they resumed feeding. For the larvae of the first instar of $M$. brasiliensis, the size measurements of the body length and weight were probably overestimated, since the individuals were collected in the field in that instar, without knowing if they had been at the beginning of the instar or not. Besides, it was not possible to obtain the biomass of the very small larvae of the first instar due to the precision of the balance nor was it possible to establish comparisons with the other instars because of the lack of precision of data. To estimate the duration of the larval period (second to third instar), only the larvae that began the instar in the laboratory were considered. The pupal size was recorded as the diameter of the cocoon and the emerged adults were measured in their body length (head to abdomen), using the calliper. 
The ratio of growth from one instar to another was obtained by dividing the head capsule width of individuals of instar (i) by the head capsule width of individuals of instar (i1). The average ratio of growth during larval development was determined as the mean of the growth ratio between instars.

The adults of $\mathrm{M}$. brasiliensis, when dead, were pinned or placed in $70 \%$ alcohol. Larvae of $\mathrm{M}$. brasiliensis, leaf-cutting ants, adults and fruit fly larvae were placed in $70 \%$ alcohol. Voucher specimens were placed in the Zoological Collection of the Universidade Federal de Mato Grosso do Sul (ZUFMS) at Campo Grande-MS, and some specimens were sent to specialists in Brazil and the USA for identification.

\section{Statistical analysis}

Analysis of variance was applied in order to verify if the different diets affected: 1 ) the duration of the larval and pupal periods; 2) the width of the head capsule ( $\mathrm{mm})$, the weight ( $\mathrm{mg}$ ) and the body length ( $\mathrm{mm}$ ) of larvae of M. brasiliensis; 3 ) the size $(\mathrm{mm})$ of the pupae; 4 ) the body length $(\mathrm{mm})$ of female and male adults, and 5) the number of consumed prey. Tukey's test for multiple comparisons was applied $(p=0.05)$. To determine if there was a significant difference in the size of the consumed and non-consumed leaf-cutting ants and consumed and non-consumed fruit fly larvae, a T-test was used. A G-test was applied to verify that the sex ratio was 1:1.

\section{RESULTS}

Duration of the larval and pupal periods

The average duration, in days, of the second and third instars differed significantly among individuals of $\mathrm{M}$. brasiliensis given different diets. In the second instar, although there were no data for the diet with only fruit fly larvae, the average duration was longer for the individuals fed with leaf-cutting ants than those on the mixed diet $\left(F_{1.14}=5.793 ; p=0.030\right)$ (Fig. 1). In the third instar, the average duration was also longer for the individuals fed with the ants $\left(F_{2.50}=25.059 ; p<0.001\right)$ compared with the fruit fly larvae or mixed diet (Tukey's test, $p<0.001$ ), but these two diets did not differ from each other (Tukey's test, $p=0.775$ ) (Fig. 1).

There was no significant difference in the duration of the pupal period among the individuals given the different diets $\left(F_{2.76}=2.595 ; p=0.081\right)$ (Fig. 1). Also, there was no significant difference in the pupal period between males and females $\left(F_{1.62}\right.$ $=2.959 ; p=0.090$ ), which averaged $25.7 \pm 4.63$ and $27.6 \pm 4.30$ (mean \pm standard deviation), respectively.

The average duration of the second and third larval stage and the pupal stage, taken together, was $167.4 \pm 38.09$ days for the larvae fed with ants and $99.8 \pm 9.42$ days (mean \pm standard deviation) for the larvae fed a mixed diet.

\section{Size of the larvae and pupae of $M$. brasiliensis}

Variation in diet did not affect the average head capsule width of the different instars of $\mathrm{M}$. brasiliensis. The difference was not significant for the first $\left(F_{2.34}=1.198 ; p=0.314\right)$, second

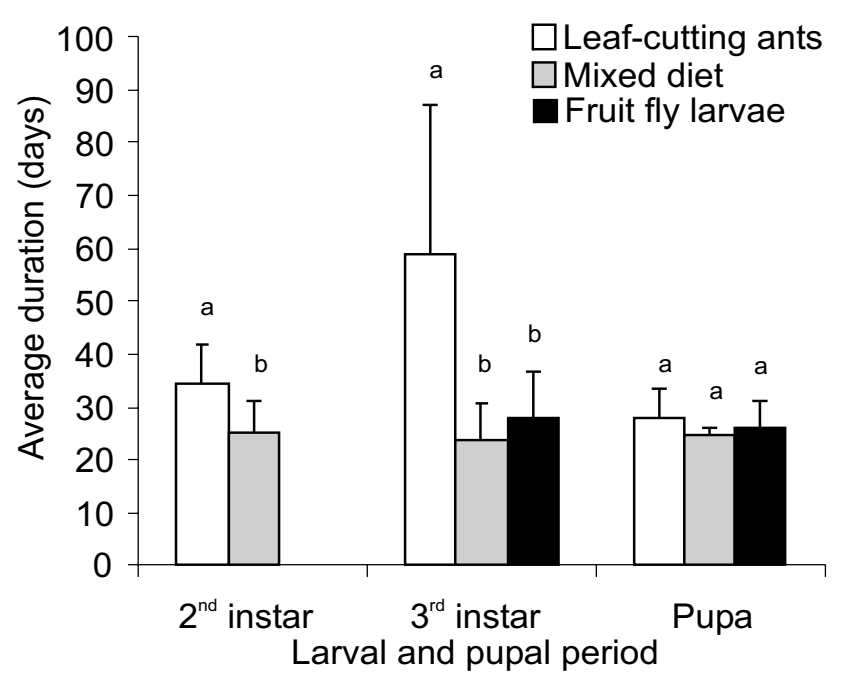

Figure 1. Average duration, in days, of the second and third larval instar and of the pupal period of $\mathrm{M}$. brasiliensis, for individuals given different diets, under laboratory conditions at average temperature of $26.0 \pm 3.50 \circ \mathrm{C}$ (mean \pm standard deviation), average relative humidity of $65.2 \pm 5.60 \%$ (mean \pm standard deviation) and 12 hours daylength. There is no difference (ANOVA and Tukey's test, $p>0.05$ ) between the columns with the same letter within each life stage.

$\left(F_{2.24}=0.309 ; p=0.737\right)$ or third instar $\left(F_{2.50}=0.770 ; p=0.468\right)$ (Fig. 2). The mean width of the head capsule of the antlion larvae was: $0.6 \pm 0.06 \mathrm{~mm}, 0.9 \pm 0.10 \mathrm{~mm}$ and $1.4 \pm 0.14 \mathrm{~mm}$ (mean \pm standard deviation), for the first, second and third instars, respectively. The average rate of growth during larval development was 1.6 (Tab. I).

Table I. Width of head capsule ( $\mathrm{mm}$ ) (mean \pm standard deviation) of $\mathrm{M}$. brasiliensis, obtained for larvae in three instars, growth ratio between instars (i) and the (i-1), and the average growth ratio during larval development.

\begin{tabular}{cccc}
\hline Instar & $\mathrm{n}$ & $\begin{array}{c}\text { Width of cephalic capsule } \\
(\mathrm{mm})\end{array}$ & Growth ratio \\
\hline $1^{\text {st }}$ & 37 & $0.6 \pm 0.06$ & 1.7 \\
$2^{\text {nd }}$ & 27 & $0.9 \pm 0.10$ & \\
$3^{\text {rd }}$ & 53 & $1.4 \pm 0.14$ & 1.5 \\
\hline \multicolumn{2}{l}{ Growth ratio average } & & 1.6 \\
\hline
\end{tabular}

Diet did not affect the average weight $(\mathrm{mg})$ of $\mathrm{M}$. brasiliensis larvae in any of the three instars. There was no significant difference for the first $\left(F_{2.17}=1.207 ; p=0.323\right)$, the second $\left(F_{2.15}=2.643 ; p=0.104\right)$ or the third instar $\left(F_{2.28}=1.336\right.$; 

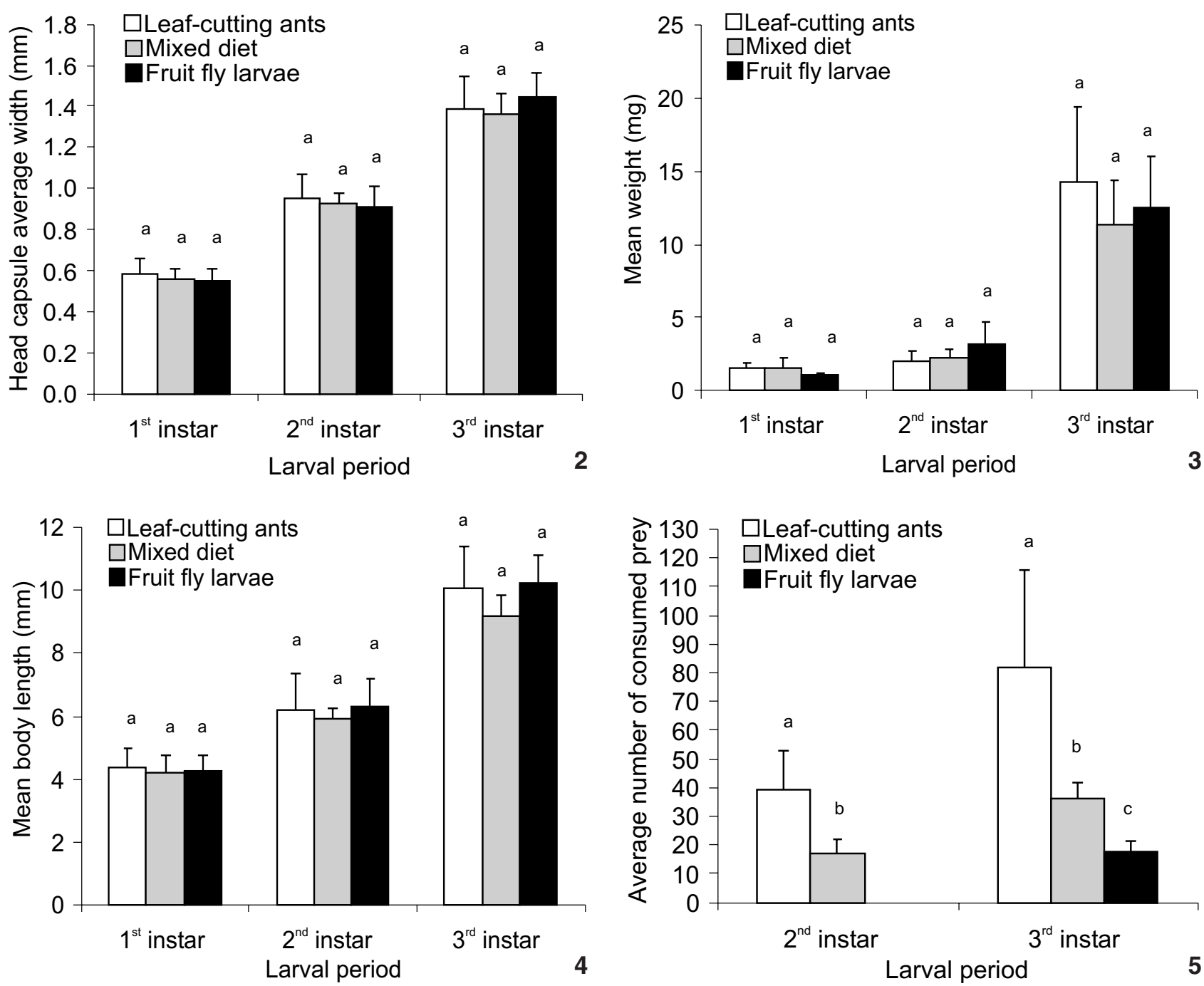

Figures 2-5. M yrmeleon brasiliensis fed with different diets [leaf-cutting ants, fruit fly larvae and mixed diet (leaf-cutting ants and fruit fly larvae)], under laboratory conditions at average temperature of $26.0 \pm 3.50 \stackrel{\circ}{ } \mathrm{C}$ (mean \pm standard deviation), average relative humidity of $65.2 \pm 5.60 \%$ (mean \pm standard deviation) and 12 hours daylength. (2) Average head capsule width (mm), (3) average weight (mg) and (4) average body length $(\mathrm{mm})$ of each instar. There is no difference (ANOVA, $p>0.05$ ) between the columns with the same letter within each life stage. (5) Average number of consumed prey, in the second and third larval instar. There is a difference (ANOVA and Tukey's test, $p>0.05$ ) in the columns with the differents letters within each life stage.

$\mathrm{p}=0.279$ ) (Fig. 3), which weighed $1.4 \pm 0.47 \mathrm{mg}, 2.4 \pm 0.94 \mathrm{mg}$ and $13.0 \pm 4.37 \mathrm{mg}$ (mean \pm standard deviation), respectively.

The kind of diet did not affect the average body length of the larvae of $M$. brasiliensis in any of the three instars. The difference was not significant in the first $\left(F_{2.36}=0.334 ; p=0.718\right)$, second $\left(F_{2.24}=0.372 ; p=0.693\right)$ or third instar $\left(F_{2.55}=2.839 ; p=0.067\right)$ (Fig. 4), which had lengths of $4.3 \pm 0.55 \mathrm{~mm}, 6.1 \pm 0.92 \mathrm{~mm}$ and $9.9 \pm 1.23 \mathrm{~mm}$ (mean \pm standard deviation), respectively. During the second and third instar the body length increased about 1.6 times. The size of the pupae of $M$. brasiliensis also did not vary significantly among individuals on different diets $\left(\mathrm{F}_{2.88}=1.825 ; \mathrm{p}\right.$ $=0.167)$. The pupae averaged $8.9 \pm 0.92 \mathrm{~mm}$ in length.

\section{Size of the consumed and non-consumed prey}

In the first, second and third instars the differences in size of the consumed and non-consumed leaf-cutting ants was significant ( $1^{\text {st }}$ instar: $t=-5.319 ; \mathrm{df}=189 ; \mathrm{p}<0.001 ; 2^{\text {nd }}$ instar: $t=-3.099 ; d f=50 ; p=0.003 ; 3^{\text {rd }}$ instar: $t=-5.826$; $d f=46$; $p<0.001$ ). However, the differences in size of the consumed and non-consumed fruit fly larvae was significant only in first 
instar ( $t=-15.193 ; \mathrm{df}=9 ; \mathrm{p}<0.001$ ), but not in the second or third instars ( $2^{\text {nd }}$ instar: $t=-0.971 ; d f=9 ; p=0.357 ; 3^{\text {rd }}$ instar: $\mathrm{t}=-0.876 ; \mathrm{df}=31 ; \mathrm{p}=0.388$ ) (Tab. II).

\section{Number of consumed prey}

In both the second and third instar, the larvae of $M$. brasiliensis fed with leaf-cutting ants consumed more prey than those fed with the mixed diet $\left(F_{1.10}=14.140 ; p=0.004\right)$ (Fig. 5). In the third instar, the larvae fed with fruit fly larvae consumed a lower number of prey than with either other diet $\left(F_{2.42}=40.061\right.$; $\mathrm{p}<0.001$ ) (Fig. 5).

Sex ratio and size of the adults of M. brasiliensis

The sex ratio of the adults of $M$. brasiliensis was $1: 1$, regardless of diet ( $G=0.56 ; p>0.05$ ). Concerning the size of the adults, the effect of interaction between diet and sex was not significant $\left(F_{2.58}=0.245 ; p=0.784\right)$, that is, the effect of the diet did not depend on the sex. The females were significantly larger than the males $\left(F_{1.58}=5.391 ; p=0.024\right)$ (Tab. III).

The kind of diet affected the size of the adults $\left(\mathrm{F}_{2.58}=9.688\right.$; $p<0.001)$. The adults whose larvae were fed with leaf-cutting ants or with a mixed diet were smaller than those whose larvae were fed with larvae of fruit flies (Tukey's test, $p<0.001$; Tab. III).

\section{DISCUSSION}

Duration of the larval and pupal periods

The longer duration of instars of $M$. brasiliensis on the diet of leaf-cutting ants than on the mixed diet and the diet of fruit fly larvae indicate that the quality of food affects the development time of this species. Although the composition of food given to $M$. brasiliensis was not analysed, as PANIzZI \& PARRA (1991) pointed out, the effect of food quality on duration of the life cycle of insects could be related to the variation in the chemical composition of the different prey.

The duration of the pupal phase of $\mathrm{M}$. brasiliensis did not vary among the diets, and the average value (27 days) was close to found out by ARnetT \& Gotell (1999a) for M. immaculatus, which duration was approximately 28 days. However, with larvae of Chrysoperla defreitasi Brooks (Neuroptera, Chrysopidae) fed with eggs of two species of Lepidoptera, Sitotroga cerealella and Diatraea saccharalis, the duration of the pupal phase was influenced by the diet, being shorter for larvae fed with $\mathrm{S}$. cerealella (BIAGIONI \& Freitas 2001). The duration of the pupal period of $M$. brasiliensis showed no significant difference be tween males and females, differing from the data found for Macroleon quinquemaculatus (Hagen) (Neuroptera, Myrmeleontidae), whose males had a shorter pupal period than the females (GRIFFITHs 1985).

The duration of the antlion life cycle depends on several factors: photoperiod, temperature, availability of prey for larvae and adults, body size, and metabolic rates, among others (FISHER 1989). The author pointed out that larvae of Myrmeleon formicarius L. in Hirosaki, Japan (a temperate region with a rigorous winter) took 1-2 years to become adults. In the present study, larvae of $\mathrm{M}$. brasiliensis reared in the laboratory starting from the first instar [under average temperature of $26.0 \pm 3.50 \circ \mathrm{C}$

Table II. Size $(\mathrm{mm})$ (mean \pm standard deviation) of the prey consumed and non-consumed by the larvae of $\mathrm{M}$. brasiliensis, in the three instars, in laboratory [under average temperature of $26.0 \pm 3.50^{\circ} \mathrm{C}$ (mean \pm standard deviation), average relative humidity of $65.2 \pm$ $5.60 \%$ (mean \pm standard deviation) and 12 hours daylength].

\begin{tabular}{|c|c|c|c|c|}
\hline \multirow{3}{*}{ Instar } & \multicolumn{4}{|c|}{ Preys } \\
\hline & \multicolumn{2}{|c|}{ Leaf-cutting ants } & \multicolumn{2}{|c|}{ Larvae of fruit flies } \\
\hline & Consumed & Non-consumed & Consumed & Non-consumed \\
\hline \multirow[t]{2}{*}{$1^{\text {st }}$} & $3.8 \pm 0.43$ & $5.2 \pm 1.91^{1}$ & $4.4 \pm 0.38$ & $8.4 \pm 0.47^{1}$ \\
\hline & $(n=51)$ & $(n=140)$ & $(n=7)$ & $(n=4)$ \\
\hline \multirow[t]{2}{*}{$2^{\text {nd }}$} & $4.1 \pm 0.36$ & $5.2 \pm 1.90^{1}$ & $8.5 \pm 2.54$ & $9.6 \pm 0.73^{1}$ \\
\hline & $(n=31)$ & $(n=21)$ & $(n=5)$ & $(n=6)$ \\
\hline \multirow[t]{2}{*}{$3^{\text {rd }}$} & $4.7 \pm 0.58$ & $6.6 \pm 1.42^{1}$ & $9.1 \pm 1.45$ & $9.8 \pm 0.35^{1}$ \\
\hline & $(n=42)$ & $(n=6)$ & $(n=30)$ & $(n=3)$ \\
\hline
\end{tabular}

${ }^{1}$ Difference in size of consumed and non-consumed prey differed significantly for that instar and prey type (T-Teste, $\left.p<0.05\right)$.

Table III. Body length (mean \pm standard deviation) of adults of $\mathrm{M}$. brasiliensis whose larvae were supplied with different diets.

\begin{tabular}{lcc}
\hline \multicolumn{1}{c}{ Diets } & \multicolumn{2}{c}{ Adult body length (mm) } \\
\cline { 2 - 3 } & $20.6 \pm 2.09 \mathrm{a}(\mathrm{n}=18)$ & Males \\
\hline Leaf-cutting ants & $20.1 \pm 1.64 \mathrm{a}(\mathrm{n}=4)$ & $19.0 \pm 0.95 \mathrm{~b}(\mathrm{n}=19)$ \\
Mixed (leaf-cutting ants + fruit fly larvae) & $22.9 \pm 2.86 \mathrm{c}(\mathrm{n}=7)$ & $21.4 \pm 1.89 \mathrm{~b}(\mathrm{n}=7)$ \\
Fruit fly larvae & $\mathrm{n}=9)$ \\
\hline
\end{tabular}

Means followed by the same letter are not different (ANOVA and Tukey's Test, $p<0.05$ ). 
(mean \pm standard deviation), average relative humidity of 65.2 $\pm 5.60 \%$ (mean \pm standard deviation) and 12 hours daylength] and fed with leaf-cutting ants or a mixed diet took around 5.5 months or 3.3 months, respectively, to become adults.

The larval and pupal stages, as a whole, were longer for the larvae fed with ants than for larvae fed with a mixed diet, even considering that the average duration of the first instar was unknown. This means that the difference in the development period might be related to the quality (chemical composition) of the ingested food in the larval phase (AuAD et al. 2001, BIAGIONI \& FREITAS 2001). Thus, among the three offered diets, that of leaf-cutting ants probably was the one with the least nutritional quality, since it resulted in a slower development of the larvae.

\section{Size of the pupae and larvae of M. brasiliensis}

The width of the head capsule and the weight and length of the body at the beginning of each instar were not different among individuals of $\mathrm{M}$. brasiliensis maintained with different diets. These results indicate that, no matter the diet, the larvae of $\mathrm{M}$. brasiliensis need to reach a certain size before molting or pupating. Therefore, although diet affects the duration of each instar, molting and pupation is determined by the size of the larvae.

The growth of insects can be evaluated through weight increase, growth of the cuticle, allometric growth and growth of tissue. Dyar's Rule predicts that the growth rate of the insects can be based on the growth of its cuticle. According to this rule, the head capsule of lepidopteran caterpillars grows in geometric progression, increasing in width at each ecdysis, in a constant ratio for a given species, varying from 1.1 to 1.9. Several authors confirmed the validity of this rule for Lepidoptera, Archaeognatha, Hymenoptera, Coleoptera and Hemiptera, including the "homopterans" Sternorrhyncha and Auchenorrhyncha, while for other groups of insects this rule seems not to be applicable (PARRA \& HADDAD 1989). The rate of growth of the head capsule of M. brasiliensis followed Dyar's Rule, with an average growth ratio during the larval development of 1.6.

From the second to the third instar, the weight of the antlion increased around 5.5 times. The weight increases through the instars, and at least doubles for each instar. As pointed out by PARRA \& HADDAD (1989), in general, larvae of instars that are not mobile have larger increments in biomass than those that move to search for food. As antlion larvae are dependent on the activity of their prey, they tend to move around when starving or under adverse conditions of habitat. So, they present a larger increase in weight when food is abundant and, where prey is scarce, they are able to move and look for a more suitable place to construct a new funnel to trap prey.

\section{Size of the consumed and non-consumed prey}

The size of the prey consumed by the larvae of $M$. brasiliensis increased in each subsequent instar, and first instar larvae that could not capture prey of a certain size (big prey), started to capture them in the next instar. When the size of a prey increases in relation to the predator, this prey becomes more difficult to capture by that predator (RICKLEFs 2000). Theoretical models predict that predators do not attack all age or size classes of a prey species with equal frequency. They subsist on several kinds of prey and the profitability of prey must be taken into account (PRICE 1997). Although this study was done in the laboratory ( $M$. brasiliensis was in cages), data on prey capture shows a pattern of predator/prey interaction.

HeINRICH \& HeINRICH (1984) found that first instar of M. immaculatus did not consume ants (Camponotus herculaneus L.) that were 9-10 mm long, although they did consume smaller ants, Leptothorax longispinosus Roger (3 mm long). In this study, the larvae $M$. brasiliensis in the first instar did not consume leaf-cutting ants larger than $5.24 \pm 1.91 \mathrm{~mm}$.

In the second and third instars, the fact that the size of the consumed ants was smaller than the size of the consumed fruit fly larvae is probably due to the higher mobility of the ants. Leaf-cutting ants larger than $5.2 \mathrm{~mm}$ present greater agility in escaping from the traps of the larvae of $\mathrm{M}$. brasiliensis and are therefore difficult to capture. The fruit fly larvae, on the other hand, are larger, but they are not as agile in escaping from the pitfall traps of $M$. brasiliensis and, for this reason, they were captured more easily.

\section{Number of consumed prey}

Thelarvae of M. brasiliensis fed leaf-cutting ants consumed more prey than those fed with the other diets, which indicates that the ants are less nutritional than the fruit fly larvae. According to PanizzI \& PARRA (1991), the beetle Propylae japonica (Coccinelidae) fed with six species of aphids, two of the species were consumed in a higher quantity and produced a faster development of the larvae of that predator. However, in this study, for the larvae of M. brasiliensis, the mixed diet and the diet with fruit fly larvae led to consumption of a lower number of prey and faster larval development. It is possible that both of these diets present higher nutritional quality than leaf-cutting ants.

\section{Sex ratio of the adults of $M$. brasiliensis}

The sex ratio for adults of $M$. brasiliensis was $1: 1$, as expected for lacewings ( $N$ Ew 1991). Regarding the body length of adults, the interaction between the effect of the diets and sex was not significant, showing that the effect of the diet is similar for both sexes. There is sexual dimorphism in the size of the adults, females being larger than males (ARNETt \& GotelLI 1999a), as is true for most insect species (CsIRo 1991).

Diet affected the size of the adults, both males and females, in that those whose larvae were fed with fruit fly larvae were larger than those whose larvae were fed with the other two diets (leaf-cutting ants or fruit fly larvae plus Atta spp.). Arnett \& Gotelli (1999a) found that adults of M. immaculatus from high-food treatments were also significantly larger than adults from low-food treatments, indicating that the fruit fly larvae in this study may present higher nutritional quality than 
the other diets.

Although Myrmeleontidae are few studied in Brazil, these results contribute to knowledge of $M$. brasiliensis biology, but also suggest the need of studies about the development of larvae and pupae in natural environments.

\section{ACKNOWLEDGEMENTS}

To Lionel A. Stange (University of Florida), for the identification of the antlion; Terezinha M.C. Della Lucia (UFV), for the identification of the leaf-cutting ants; José A. Uchôa Fernandes (USP) and Elsbeth A. Flunker (WI) for the final revision of the English version and CAPES for the grant to the first author.

\section{REFERENCES}

Arnett, A.E. \& N.J. Gotellı. 1999a. Geographic variation in lifehistory traits of the antlion, Myrmeleon immaculatus: evolutionary implications of Bergmann's rule. Evolution, Lancaster, 53 (4): 1180-1188.

Arnett, A.E. \& N.J. Gotelli. 1999b. Bergmann's rule in the ant Iion Myrmeleon immaculatus DeGeer (Neuroptera: Myrmeleontidae): geographic variation in body size and heterozygosity. Journal of Biogeography, Oxford, 26: 275283.

Arnett, A.E. \& N.J. Gotelli. 2001. Pit-building decisions of larval antlions: effects of larval age, temperature, food, and population source. Journal of Insect Behavior, New York, 14 (1): 89-97.

Auad, A.M.; L.C. Toscano; A.L. Boiça Júnior \& S. Freitas. 2001. Aspectos biológicos dos estádios imaturos de Chrysoperla externa (Hagen) e Ceraeochrysa cincta (Schneider) (Neuroptera: Chrysopidae) alimentados com ovos e ninfas de Bemisia tabaci (Gennadius) Biótipo B (Hemiptera: Aleyrodidae). Neotropical Entomology, Londrina, 30: 429432.

Biagioni, A. \& S. Freitas. 2001. Efeito de diferentes dietas sobre o desenvolvimento pós-embrionário de Chrysoperla defreitasi Brooks (Neuroptera: Chrysopidae). Neotropical Entomology, Londrina, 30: 333-336.

CSIRO. 1991. The Insects of Australia: a textbook for students and research workers. Ney York, Cornell University Press, $2^{\text {nd }}$ ed., vol. 1, 542p.

FiSHER, M. 1989. Antlion life cycles in Nigeria. Journal of Tropical Ecology, Cambridge, 5: 247-250.
Gotellı, N.J. 1993. Antlion zones: causes of high-density predator aggregations. Ecology, Brooklyn, 74: 226-237.

GotelLI, N.J. 1997. Competition and coexistence of larval antlions. Ecology, Brooklyn, 78: 17611773.

GrifFITHS, D. 1985. Phenology and larval-adult size relations in the ant-lion Macroleon quinquemaculatus. Journal of Animal Ecology, London, 54: 573-581.

HeINRICH, B. \& M.J.E. HeINRICH. 1984. The pit-trapping foraging strategy of the ant lion, Myrmeleon immaculatus DeGeer (Neuroptera: Myrmeleontidae). Behavioral Ecology and Sociobiology, New York, 14: 151-160.

LUCAS, J.R. 1989. The structure and function of antlion pits: slope asymmetry and predator-prey interactions. Animal Behaviour, London, 38: 318-330.

LucAs, J.R. \& L.A. Stange. 1981. Key and descriptions to the M yrmeleon Iarvae of Florida (Neuroptera: Myrmeleontidae). Florida Entomologist, Gainesville, 64 (2): 207-216.

Matsura, T. 1987. An experimental study on the foraging behavior of a pit-building antlion Iarva, Myrmeleon bore. Researches on Population Ecology, Kyoto, 29: 17-26.

NEw, T.R. 1991. Neuroptera, p. 525-542. In: CSIRO (Ed.). The Insects of Australia: a textbook for students and research workers. Melbourne, Melbourne University Press, $2^{\text {nd }}$ ed., vol. 1, 1137p.

PanizzI, A.R. \& J.R.P. ParRa. 1991. Ecologia nutricional de insetos e suas aplicações no manejo de pragas. São Paulo, Manole, CNPQ, 359p.

PARRA, J.R.P. \& M.L. HADDAD. 1989. Determinação do número de instares de insetos. Piracicaba, FEALQ, 49p.

PRICE, P.W. 1997. Insect Ecology. New York, John \& Sons, $3^{\text {rd }}$ ed., 874p.

Ricklefs, R.E. 2000. Ecology. New York, Freeman, $4^{\text {th }}$ ed., 822p.

StANGE, L.A. 2004. A systematic catalog, bibliography and classification of the world antlions (Insecta: Neuroptera: Myrmeleontidae). Gainesville, American Entomological Institute, 565p.

Topoff, H. 1977. The pit and the antlion. Natural History, New York, 86: 65-71.

UChÔA-Fernandes, M.A. \& R.A. Zucchi. 1999. Metodologia de colecta de Tephritidae y Lonchaeidae frugívoros (Diptera: Tephritidae) y sus parasitoides (Hymenoptera). Anais da Sociedade Entomológica do Brasil, Londrina, 28: 601-610. WILSON, D.S. 1974. Prey capture and competition in the ant Iion. Biotropica, Washington, 3: 187-193.

Received in 16.II.2006; accepted in 03.X.2006. 